\title{
特別検討症例
}

\section{Merkel Cell Carcinoma}

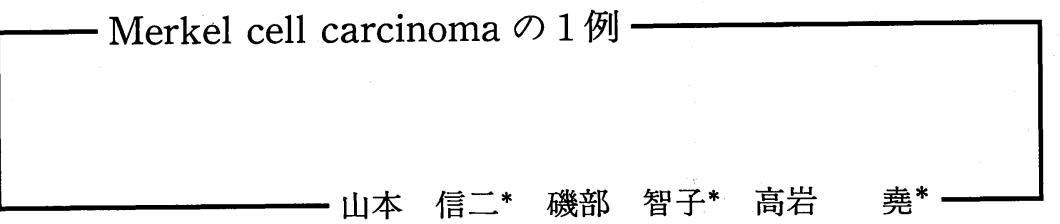

Summary

89歳女性。右頓部の鶏卵大の紫紅色ドーム状腫瘤と右䅡部リンパ節転移を認めた。遠隔 転移は認めなかった。組織学的には travecular pattern を示し, 免疫組織化学的には NSE 陽性で，血清 NSE 值も高値であった。電顕的には dense core granule を認めた。電子線 照射にてほぼ痈痕治癒するも, DIC 併発し初診より 2 カ月後に死亡した。死亡直前に, 逆 側の左耳下腺部と左下顎部に転移性皮下腫瘤が出現した。

はじめに

Merkel cell carcinoma は, 1972年 Toker ${ }^{1} に$ より “travecular carcinoma of the skin” の名 称で初めて紹介された。その後, 電顕的観察よ クメルケル細胞に類似していることから Merkel cell carcinoma と命名された。しかし，メ ルケル細胞に由来するという考えには，近年多 くの異論が唱えられるようになってきた。かつ ては, 非常に稀な腫瘍と考えられていたが, 1980 年頃より多くの報告がみられるようになり，欧 米では現在までに400例以上の報告がされてい る2)。最近，我々は，逆側䅡部へ転移をきたした 右煩部の Merkel cell carcinoma の 1 例を経験 したので報告する。

*Shinji YAMAMOTO, Tomoko ISOBE, Takashi TAKAIWA：香川医科大学皮膚科学教室

症例

患 者: 89 歳, 女性
初 診: 平成元年 6 月 4 日

既往歴, 家族歴：特記すべきことなし。

現病歴：平成元年12月頃，右頓部に「ハ夕ケ」 様の白い斑があるのに気付く。平成 2 年 2 月中 旬頃, 同部に腫瘤が出現し, 徐々に増大するよ うになったため, 同年 6 月 4 日当科を受診した。

現 症：右頓部に $47 \times 47 \times 23 \mathrm{~mm}$ の表面に 穢褐色の痂皮を付着する紫紅色より常色のドー ム状腫瘤をみる。弾性硬。下床とはわずかに可 動。この皮虐腫瘤に近接し, 胸鎖乳突筋に沿う ように並ぶ鶏卵大以下の硬い皮下腫瘤を 4 個触 知する。いずれも，下床と癒着し表皮とは可動 性がある（図 1）。

臨床検査所見：一般検查成績では, LDH 621 $\mathrm{U} / \mathrm{m} l$ と上昇している以外に著変はみられな い。腫瘍マーカーでは, CEA 2.6ng $/ \mathrm{m} l, \beta_{2}$-ミ クログロブリン $3.4 \mathrm{mg} / \mathrm{d} l$ の上昇と, $\mathrm{NSE}$ (non- specific esterase) $69.8 \mathrm{ng} / \mathrm{m} l$ (正常值10 


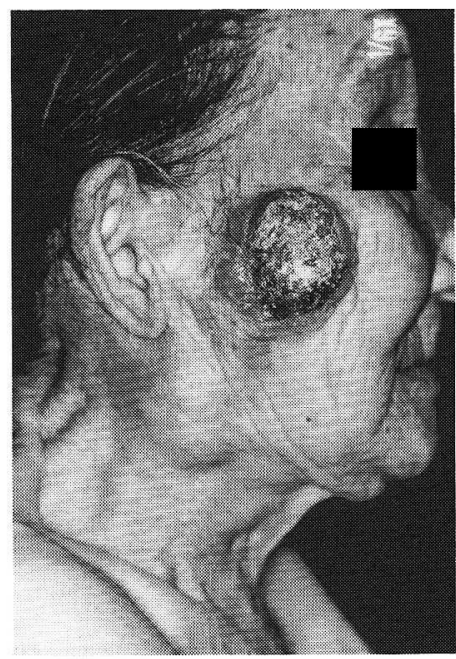

図 1. 初診時臨床像 右頓部皮䖉腫瘍と頝部リンパ節転移

以下) の著しい上昇がみられた。 $\alpha$-フェトプロ テイン, SCC 抗原は正常範囲内であった。頭部, 胸腹部 $\mathrm{X}$ 線, 頭部, 頚部, 胸腹部 $\mathrm{CT}, \mathrm{Ga}$ シン チにて右煩部〜右䅡部以外の他蔵器に腫瘍を思 わせる所見はなかった。

病理組織所見：真皮内に稠密な腫瘍細胞の増 殖がみられる。表皮は平坦化し，表皮下には明 瞭な grenz zone が認められる (図 2 )。この細 胞集塊は部分的に travecular pattern を示す。 個々の腫瘍細胞は小型でクロマチンに富み分裂 像や壊死像のみられるものと, やや大型でク口 マチンにそしく分裂像のほとんどみられないも のよりなる。いずれも腫瘍細胞は均一で胞体に そしく, 主に類円形の平滑な核を有する(図 3)。 特殊染色では, PAS, Grimelius, Bodian, leucocyte common antigen (LCA), S-100蛋白, Neurofilament, Keratinはいずれも院性で あったが, neuron specific enolase (NSE) は 陽性であった。

電子顕微鏡所見：核は類円形で，1２個の 核小体を有する。個々の細胞は, 細胞質突起が 複雑にからまりあい結合している。Microvilli や不完全な desmosome 様構造も散見される。 細胞質内には，ゴルジ装置やミトコンドリア， 多数のポリゾームが認められる。一層の限界膜

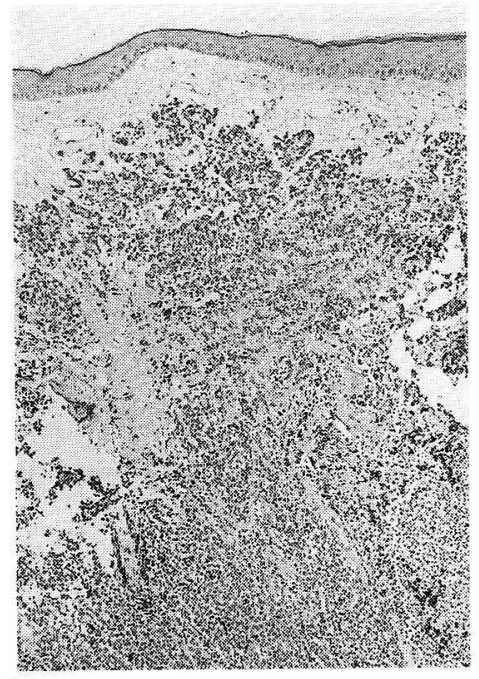

図 2. 生検標本組織像 (右㥧部原発巣) 明瞭な grenz zone がみられる

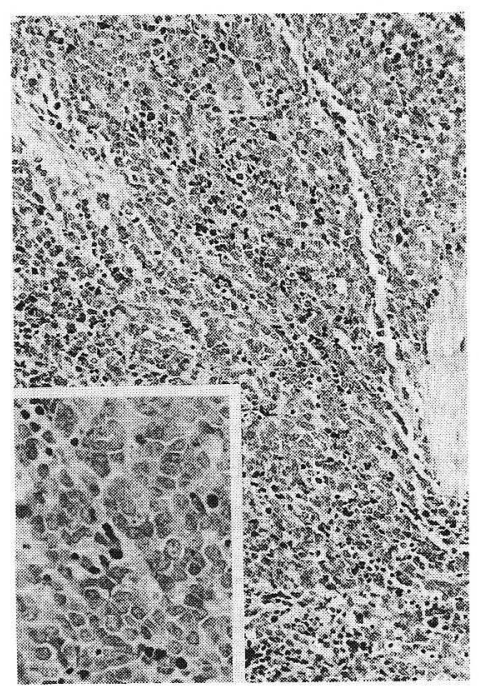

図 3. 生検標本組織像（右煩部原発巣）

腫湢細胞巣は travecular pattern を示す 挿困：腫淘細胞は 2 種類の均一な細胞よりなる

と clearな haloを有する dense core granule もみられたが，その数は少なく，ほとんどは細 胞質突起内にあった。また, 細胞質突起内に intermediate filament の集塊も認められた（図 4 )。

経過および治療：高齢であることより，外科 的治療および化学療法は, 不可能と判断した。 腫瘍の二次感染に対し抗生剂投与を行うととも 


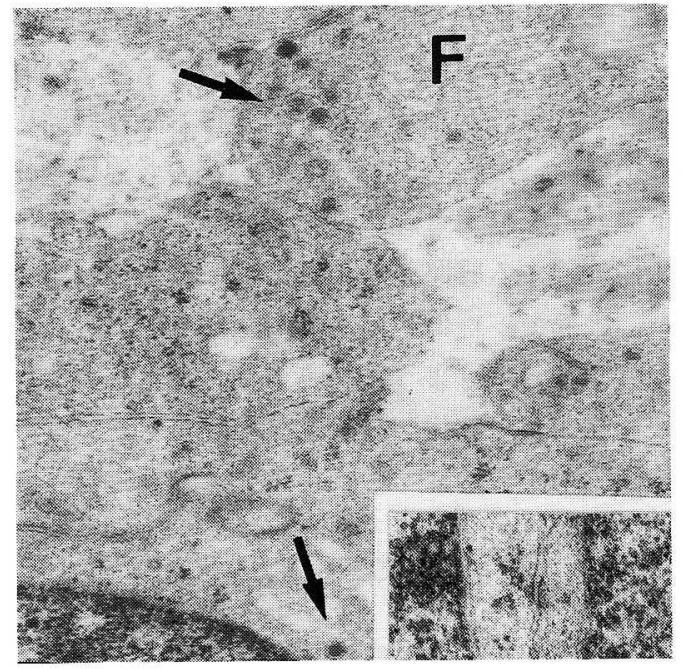

図 4 . 電顕像

dense core granule (A)

intermediate filament $(F)(\times 24,000)$

挿図: desmosome 様構造 $(\times 25,000)$

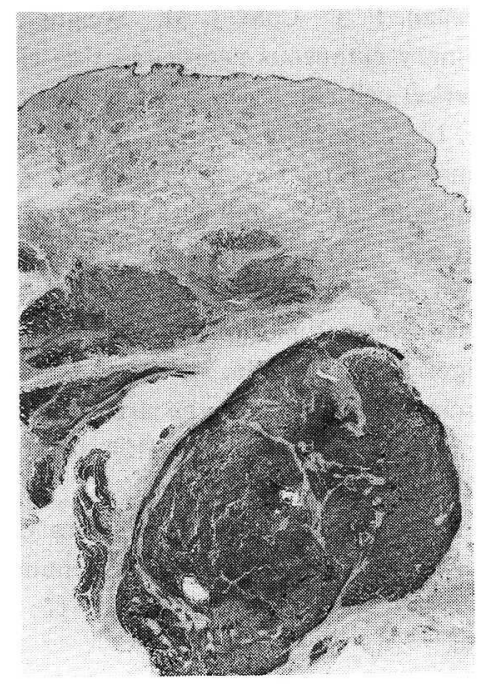

図 6. 左下顎部組織像

被膜を有する皮下の腫瘍塊と真皮内の 腫瘍細胞の浸潤性增殖

に，6月15日より右煩部および右頝部に電子線 照射 ( $2 \mathrm{Gr} /$ day, $5 \mathrm{fr} / \mathrm{W}$ ) を開始した。しか し， 7 月 5 日より chronic DIC を併発し全身状 態が悪化したため電子線照射は総量28Gy で中 止したが, 腫瘍は瘢痕治癒した。その後, 更に 全身状態悪化し，8月 7 日永眠した。

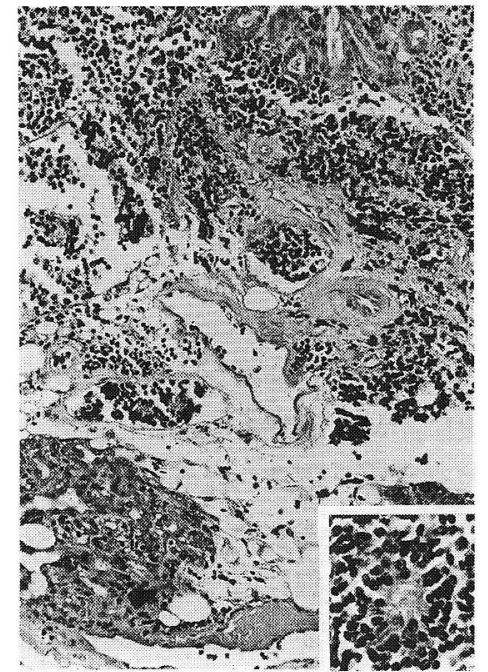

図 5. 左䅡部皮下腫瘤組織像

脈管内への腫瘍細胞の浸潤と pseudorosette（挿図）がみられる

死亡 5 日前, 皮虞腫瘍と逆側の左頝部と左下 䫟部に，それぞれ $12 \times 12 \mathrm{~mm}$ と $18 \times 12 \mathrm{~mm}$ の皮 下腫瘤が出現した。剖検はできなかったが, 死 亡後この皮下腫瘤を切除することができた。

左䅡部皮下腫瘤病理組織所見：耳下腺と思わ れる漿液腺と腫瘤塊がみられる。腫瘤塊のリン 八゚節様構造は明らかではない。個々の腫瘍細胞 は右煩部皮膚腫瘤と同一の形態を示すが，その 配列に travecular な傾向は少なくなり, 細胞間 吵が広く散在性に分布する部分が多い。脈管内 への浸潤や pseudorosetteも認められる（図 5 )。

左下顎部皮下腫瘤病理組織所見：被膜に被わ れた立実性の腫瘍塊と, 組織間隙にしみ込むよ うに浸潤している腫陽細胞がみられる（図６）。 腫瘍細胞は右頓部皮膚腫瘍と同一のもので，リ ンパ管内への浸潤や pseudorosette も認められ る。

\section{考按}

Merkel cell carcinoma の起源については汗 腺上皮，メルケル細胞， pluripotent basal cell， 
真皮内神経内分泌細胞（メルケル細胞とは限ら ない）が考えられている3゙が，いわゆる APUD 系腫瘍としての性質を有することと，抗ケラチ ン抗体陽性, 細胞間のデスモゾーム様構造がみ られるなど上皮細胞由来を示唆する多くの症例 があるということに異論はないものと思われ る。すなわち, Merkel cell carcinoma は上述 の 2 つの性格を合わせ持った腫痬ということに なる。更に, Merkel cell carcinoma は同一部 位に有棘細胞癌を併発したり, 有棘細胞癌への 移行がみられることがある4)。これらの所見は, $2 つ の$ 異なった細胞に同一の発癌刺激が加わっ たというよりも，2つの腫瘍が共通の祖先であ る pluripotent basal cell より生ずると考える5) 方が理解し易い。すなわち, Merkel cell carcinomaは表皮の pluripotent stem cell が神経 内分泌細胞方向へ分化したと考えられる ${ }^{6)}$ のような考えは, 肺の small cell carcinoma で は既に広く受け入れられている。

本腫瘍は他の APUD 系腫瘍, 特に肺や消化 器の small cell carcinoma とは細胞形態, 免疫 組織化学的所見, 電顕所見のいずれも類似して いるため組織学的に鑑別は困難であるとされて いた。Johansson らフによると small cell carcinoma は光顕的に travecular pattern は呈さ ないと報告している。また，サイトケラチン CAM 5.2の染色所見で比較すると, Merkel cell carcinoma では80\%paranuclear globular pattern が認められるが, small cell carcinoma では稀にしか認められないと報告している。し かし, small cell carcinoma でも時に globular pattern を呈するため，この所見に頼り過ぎる 危険性も唱えられている ${ }^{3)}$ 。

自験例は内臓に原発巣を思わせる所見がな く, 組織学的にも travecular pattern がみられ
たことより Merkel cell carcinoma と考えた。 ところが，死亡直前に逆側の下顎皮下および耳 下腺への転移が出現した。考之得る転移経路と しては，一度他の部位へ転移したのち更に逆側 下顎部に転移する経路と, 直接リンパ行性に逆 側に転移する経路が考えられる。後者の経路は 時に乳癌で, 一例えば右乳房の乳癌が左乳房へ 転移するというように一みられることがある。 残念ながら，剖検が施行できなかったため，転 移経路を明らかにすることはできなかった。

\section{文献}

1) Toker, C.: Travecular carcinoma of the skin. Arch. Dermatol. , 105 : 107-110, 1972.

2) Kayashima, K., Ono, T., et al.: Spontaneous regression in Merkel cell (Neuroendocrine) carcinoma of the skin. Arch. Dermatol., 127 : 550-553, 1991.

3 ) Heenan, P. J., Cole, J. M., Spagnolo, D. V.: Primary cutaneous neuroendocrine carcinoma (Merkel cell carcinoma). Am. J. Dermatopathol. , $12: 7-16,1990$.

4) Tang, C. K., Toker, C., et al.: Unusual cutaneous carcinoma with features of small (oat cell-like) and squamous cell carcinomas: A variant of malignant Merkel cell neoplasm. Am. J. Dermatopathol. , 4 : 537-548, 1982.

5 ) Frigerio, B., Capella, C., et al.: Merkel cell carcinoma of the skin : the structure and origin of normal Merkel cells. Histopathology, 7 : 229-249, 1983.

6 ) Drijkoningen, M., De Wolf-Peeters, C., et al. : Merkel cell tumor of the skin. An immunohistochemical study. Hum. Pathol., 17: 301-307, 1986.

7) Johansson, L., Tennvall, J., Akerman, M.: Immunohistochemical examination of 25 cases of Merkel cell carcinoma : A comparison with small cell carcinoma of the lung and oesophagus, and a review of the literature. APMIS, 98 : 741-752, 1990. 